\title{
Modeling energy savings in low income residencies
}

\author{
C. G. Morales \& A. J. Malavé \\ PREC - Puerto Rico Energy Center, Universidad del Turabo, \\ Gurabo, Puerto Rico
}

\begin{abstract}
We evaluate the energy efficiency corresponding to the construction of low income residences in Puerto Rico. These units are characterized by areas of $800 \mathrm{ft}^{2}, 3$ bedrooms, one bathroom, reception room, dining room and kitchen. We model residences built under the latest International Energy Conservation Code (IECC 2009) included in recent American Recovery and reinvestment Act legislation, proposing changes in the materials used in their constructions. Our models compare: a) the case of building with typical materials and construction practices used in Puerto Rico, with b) the case where materials and techniques recommended by the new code are used. We show that the use of our modified specifications results in a monthly electrical energy saving of $\$ 54$ for flat roof constructions (39\% saving), and a $\$ 60$ (41\% saving), monthly saving for the case of constructions with gabled roofs. We use two computer models: a) a design model for the house construction, b) the public domain program Energy available from the US department of energy. We use climate conditions corresponding to the region near the city of San Juan.
\end{abstract}

Keywords: energy savings, building modelling.

\section{Introduction}

As part of the American Recovery and Reinvestment Act of 2009 Puerto Rico must comply with new buildings regulations. These regulations were designed to minimize energy consumption in all new structures. Their application could have an important impact on construction costs affecting the residential housing industry and the public in general. 
The ARRA act includes a disposition for the application of energy conservation standards set by the International Energy Conservation Code in its latest version of 2009 "IECC 2009". Under this code Puerto Rico is considered part of zone 1 together with Hawaii, U.S Virgin Islands, Guam, Mariana Islands and a small portion of southeastern Florida. If the IECC 2009 were to be applied directly in Puerto Rico the construction materials and methods would be altered significantly. Such alteration would have a profound impact on the construction costs of the social interest houses (any housing structure with less than $1000 \mathrm{ft}^{2}$ ). The Energy Affairs Office and the Home Builders Association of Puerto Rico suggested the need to model energy consumption in structures developed under traditional methods and with the new standards. The results obtained from this study would provide the basis for the energy conservations amendments that would be included in the Puerto Rico building code. Up to the present there was no accurate information on the thermal envelop characteristics of a typical social interest house. In Table 1 is seen the suggested $\mathrm{R}$ values or thermal resistance on the different components of the house, before that study P.R. did not have suggested values as a results of no having a complete energy code.

Table 1: $\quad$ Suggested thermal resistance values of IECC2009 and Puerto Rico typical values.

\begin{tabular}{|c|c|c|}
\hline Suggested R values & $\begin{array}{c}\text { Table 402.1.3 } \\
\text { IECC 2009 }\end{array}$ & $\begin{array}{c}\text { Suggested values } \\
\text { in PR }\end{array}$ \\
\hline Fenestration factor & 1.2 & N/A \\
\hline Skylight, U factor & 0.75 & N/A \\
\hline Ceiling, U Factor & 0.035 & N/A \\
\hline Frame Wall, U Factor & 0.082 & N/A \\
\hline Mass Wall, U Factor & 0.197 & N/A \\
\hline $\begin{array}{c}\text { Floor, U Factor } \\
\text { Basement Wall, U Factor }\end{array}$ & 0.064 & N/A \\
\hline $\begin{array}{c}\text { Craw Space } \\
\text { U Factor }\end{array}$ & 0.477 & N/A \\
\hline \multicolumn{2}{|c}{} & \\
\hline
\end{tabular}

The energy modeling was performed using: 1) drawings software to develop the computerized models and the 2) EnergyPlus a public domain software designed by the US Department of Energy to model energy and water consumption in buildings [3].

The building materials and methods used in Puerto Rico have changed dramatically in the last 100 years. The residential buildings went from wood walls and zinc roofs to an all concrete structure by the 1950s. There were 
multiple reasons for these changes, the main one being the increase in wood prices combined with a strong population growth. Puerto Rico had a building code that has been barely modified since 1950 [5]. In 1997 the Uniform Building Code was adopted and was still in use until the adoption of a new code in 2011. This code was not modified during its implementation. Due to the increase in electricity costs due to the increase in petroleum cost and the awareness of climate change a change in perception on energy consumption was experienced at both the governmental and private sector and subsequently the need for an energy conservation code arose. As a starting point the energy conservation codes of countries and regions with similar weather conditions as Puerto Rico were analyzed as was the case with Hawaii's Energy conservation code. The standards provided in those codes gave us the idea to perform the present simulations that can be of great value in order to establish our own energy code.

\section{Simulation description}

In humid tropical weather the main factor in the energy consumption of a building is air conditioning system. For our study the residential building was assumed to be either all conditioned (air conditioning system available to all living space) or partially conditioned ( air condition system was available only at the master bedroom). In total 26 simulations were performed, 13 for each air conditioning case. The simulations were performed for two structural cases:

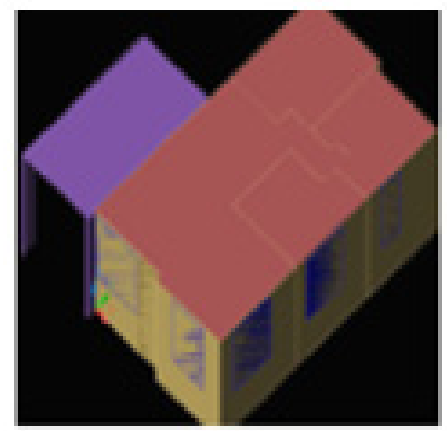

Figure 1: Flat roof model a. roof height $8 \mathrm{ft}$ b. roof height $9 \mathrm{ft}$.

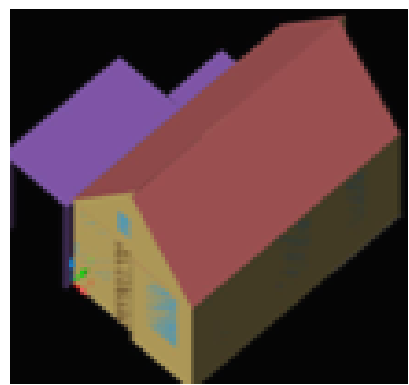

Figure 2: Gabled roof.

The simulations were made to exactly replicate a typical social interest house in Puerto Rico, which has an area living of $830 \mathrm{ft}^{2}$, including 3 bedrooms, 1 bathroom, dining room, living room and a kitchen as it can be seen in the house layout "figure 3". This design was provided by the Home Builders Association of Puerto Rico and was used as the baseline model. The baseline was used to compare how well different materials and conditions fared against the actual energy consumption at these types of structures. 


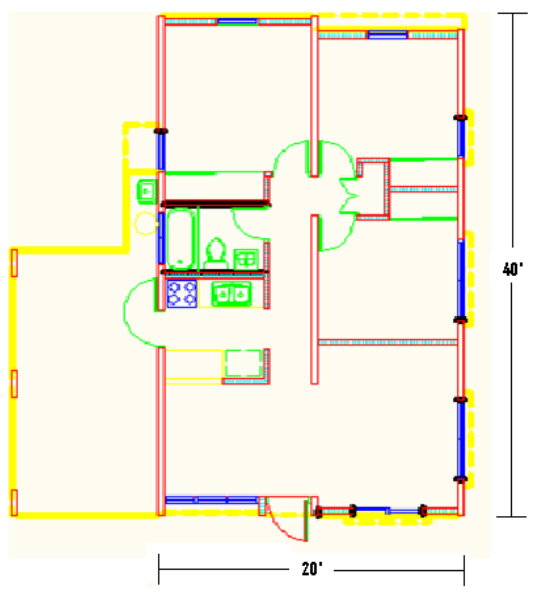

Figure 3: Typical social interest house in Puerto Rico.

The baseline properties were as follows:

- Electrical water heater

- Incandescent bulbs

- Appliances; (refrigerator, stove, etc.)

- Typical construction materials (5in thick concrete walls, paint)

The suggested improvements were as follows:

- Solar water heater

- Fluorescent bulbs

- Appliances; (fridge, stove, etc.)

- Typical construction materials (5in thick concrete walls, paint) and non-typical construction materials (foam, insulators, etc)

Besides the construction materials and the number appliances the simulations require inputs based on the activities performed at the house in order to determine the time energy is been consumed. For this reason the typical behavior of a family of 4 members, in which the family members will be active at the house from $3 \mathrm{pm}$ to $11 \mathrm{pm}$ at night and small interval in the mornings during weekdays and at full time during weekends. With this information the software models the energy consumption per day and per hour generated by human activities. In the figure 4 is shown the process to make a complete simulation; the first step is design the house and import on the EnergyPlus software, the second step consist in add all the inputs on IDF Editor Energy Plus. After that you can run the simulation using the launch of EnergyPlus. When the simulation is over you can collect data and analysis all of them. The input information was the electricity cost per $\mathrm{kW}-\mathrm{hr}$, the projection factor and the solar heat gain through the windows as seen in table 2. 


\section{Simulation Process}

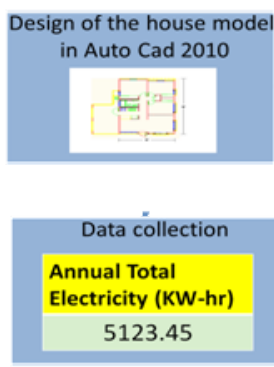

Figure 4: $\quad$ Step by step simulation process.

Table 2: $\quad$ Additional data input.

\begin{tabular}{|c|}
\hline Additional Data \\
\hline Electricity cost : $\$ 0.224 / \mathrm{KW}-\mathrm{hr}$ \\
\hline Projection factor $(\mathrm{PF})=0.5$ \\
\hline $\begin{array}{c}\text { Solar heat gaining factor }=0.75 \\
\text { (obtained from ASHRAE }- \text { Miami } \\
\text { Windows) }\end{array}$ \\
\hline
\end{tabular}

\subsection{Materials}

The construction materials used for the simulations are shown in table 3. All the materials used in the simulations are in the market and available in Puerto Rico Each simulation was done using different design combinations of walls, roof and floors as can be seen in table 4 . Each case has a distinctive thermal resistance value (R-value). The goal of the simulations is to suggest a thermal envelope for the structure with an R-value of at least $15 \mathrm{~m}^{2} \mathrm{~K} / \mathrm{W}$, which is half the value proposed at the IECC 2009, but accepted by the US department of Energy as a good starting point. The actual R-value for a typical house in Puerto Rico is 0.44.

The baseline was selected as the typical social interest house with 5 in concrete walls, roof and floors. The walls have an additional stucco layer. All the other simulations were done by altering the baseline as can be seen in Table 4, where the main modification was the increase of the insulation to the envelope and the change in the construction materials, and in some instances the design of the structure (gabled roofs). The windows were made with thin blades aluminum with a high thermal conductivity and thereby a low thermal resistance that are traditionally called "Miami" style. The internal loads considered were electrical appliances, illumination and the amount of occupants. Three types of roofs were considered flat roof with $8 \mathrm{ft}$ height, flat roof with $9 \mathrm{ft}$ height and a gabled roof "Figure 1 and 2". The baseline was modeled using a electrical water heater, for all other conditions a solar water heater was used. 
Table 3: $\quad$ Materials used for the design of the houses in simulations case.

\begin{tabular}{|c|c|c|c|}
\hline Material & $\begin{array}{l}\text { Mechanical } \\
\text { properties }\end{array}$ & $\begin{array}{l}\text { Suggested } \\
\text { material }\end{array}$ & Mechanical properties \\
\hline $\begin{array}{l}\text { Concrete } \\
5 \text { "' }-8 \text { ", } \\
\text { (Roof, } \\
\text { Wall, } \\
\text { Floor) }\end{array}$ & $\begin{array}{l}\text { Rough } \\
\text { Conductivity=0.19 } \\
4(\mathrm{~W} / \mathrm{m}-\mathrm{K}) \\
\text { Density } \\
=2240\left(\mathrm{~kg} / \mathrm{m}^{3}\right) \\
\text { Specific heat } \\
=921(\mathrm{~J} / \mathrm{kg}-\mathrm{K})\end{array}$ & $\begin{array}{l}\text { Paint } \\
\text { Coating }\end{array}$ & $\begin{array}{l}\text { Rough } \\
\text { Thermal resistance } \\
=7.87 \mathrm{E}-08 \\
\mathrm{~m}^{2} \mathrm{~K} / \mathrm{W}\end{array}$ \\
\hline $\begin{array}{l}\text { Wood } \\
\text { Doors }\end{array}$ & $\begin{array}{l}\text { Medium Rough } \\
\text { Conductivity } \\
=0.153 \mathrm{~W} / \mathrm{m}-\mathrm{k} \\
\text { Density } \\
=6800 \mathrm{~kg} / \mathrm{m}^{3} \\
\text { Specific heat } \\
=1.63 \mathrm{E}+02 \mathrm{~J} / \mathrm{kg}-\mathrm{k}\end{array}$ & $\begin{array}{l}\text { Attic acoustic } \\
\text { ceiling }\end{array}$ & $\begin{array}{l}\text { Medium Rough Thermal } \\
\text { resistance } \\
=0.054 \\
\mathrm{~m}^{2} \mathrm{k} / \mathrm{W} \\
\text { Thermal absorbance } \\
=0.84\end{array}$ \\
\hline \multirow[t]{3}{*}{$\begin{array}{l}\text { Aluminum } \\
\text { (Windows) }\end{array}$} & $\begin{array}{l}\text { smooth } \\
\text { Conductivity } \\
=1.85 \mathrm{E}+01 \mathrm{w} / \mathrm{m}-\mathrm{k} \\
\text { Density } \\
2.74 \mathrm{E}+03 \\
=\mathrm{kg} / \mathrm{m}^{3} \\
\text { Specific heat } \\
=8.95 \mathrm{E}+02 \mathrm{~J} / \mathrm{kg}-\mathrm{k}\end{array}$ & $\begin{array}{l}\text { Insulate } \\
R-5\end{array}$ & $\begin{array}{l}\text { Medium Rough Thermal } \\
\text { Resistance } \\
=8.81 \mathrm{E}-01 \\
\mathrm{~m}^{2} \mathrm{k} / \mathrm{W} \\
\text { Thermal Absorbance } \\
=0.9\end{array}$ \\
\hline & & Cool Roof & $\begin{array}{l}\text { Medium } \\
\text { Rough Thermal resistant } \\
=2.64 \mathrm{E}+02 \\
\mathrm{~m}^{2} \mathrm{k} / \mathrm{w} \\
\text { Thermal Absorbance } \\
=0.7\end{array}$ \\
\hline & & $\begin{array}{l}\text { Window } \\
\text { Material } \\
\text { Glazing } \\
\text { Clear }\end{array}$ & $\begin{array}{l}\text { Thickness } \\
=3 \mathrm{~mm} \\
\text { Solar Transmit } \\
=0.837\end{array}$ \\
\hline
\end{tabular}


Table 4: $\quad$ Cases studied.

\begin{tabular}{|c|c|c|}
\hline Case & Material used at roof and walls & R -Value \\
\hline $\begin{array}{l}\text { A } \\
\text { (base) + }\end{array}$ & $\begin{array}{l}\text { 1)Concrete 5" } \\
\text { 2)Paint Coating }\end{array}$ & $R-0.44$ \\
\hline $\mathbf{B}+$ & IECC 2009 & $\mathrm{R}-30$ \\
\hline $\mathrm{C}^{*}$ & $\begin{array}{l}\text { 1)Cool Roof } \\
\text { 2)Concrete 5" } \\
\text { 3)Paint coating }\end{array}$ & $R-15$ \\
\hline $\mathbf{D}^{*}$ & $\begin{array}{l}\text { 1)Cool Roof } \\
\text { 2)R-5 insulation } \\
\text { 3)Concrete 5" } \\
\text { 4)Paint Coating }\end{array}$ & $\mathrm{R}-15$ \\
\hline $\mathbf{E}^{*}$ & IECC2009 & $\mathrm{R}-30$ \\
\hline$F^{*}$ & $\begin{array}{l}\text { 1) Gabled roof } \\
\text { 2)Attic ceiling }\end{array}$ & $\mathrm{R}-0.44$ \\
\hline$G^{*}$ & $\begin{array}{l}\text { 1) Gabled roof } \\
\text { 2)Cool Roof } \\
\text { 3)Attic ceiling }\end{array}$ & $\mathrm{R}-15$ \\
\hline $\mathbf{H}^{*}$ & $\begin{array}{l}\text { 1)Gabled roof } \\
\text { 2)NO Attic }\end{array}$ & $R-0.44$ \\
\hline $\mathbf{I}^{*}$ & $\begin{array}{l}\text { 1)Cool Roof } \\
\text { 2) Gabled roof } \\
\text { 3) NO Attic }\end{array}$ & $R-15$ \\
\hline $\mathbf{J} *$ & 1)Roof $9 \mathrm{ft}$ & $R-0.44$ \\
\hline $\mathbf{K}^{*}$ & $\begin{array}{l}\text { 1)Cool Roof } \\
\text { 2)Roof 9ft }\end{array}$ & $\mathrm{R}-15$ \\
\hline $\mathbf{L}^{*}$ & $\begin{array}{l}\text { 1)Concrete 5" } \\
\text { 2)Paint Coating }\end{array}$ & R-0.44 \\
\hline $\mathbf{M}^{*}$ & $\begin{array}{l}\text { P.R. Energy Code } \\
\text { 1)Concrete 5" } \\
\text { 2)Cool Roof } \\
\text { 3)Paint Coating }\end{array}$ & \\
\hline
\end{tabular}

$+=$ Electrical water heater.

*= Solar water heater.

P.R. energy code includes SHGC de .40 and a fenestration value of 1.2. 


\section{Results}

The results of the simulations are shown in Tables 5 and 6 . Table 5 shows the results of the house with only one air conditioning unit for the master bedroom; table 6 shows the results of houses with 3 air conditioning units. The results from the simulation are the annual cooling electricity consumption $(\mathrm{kW}-\mathrm{h})$, total electricity consumption (kW-h), annual electricity costs and energy costs savings

Table 5: $\quad$ Results with one air conditioning unit.

\begin{tabular}{|c|c|c|c|c|c|c|}
\hline Case & $\begin{array}{c}\text { Annual } \\
\text { Cooling } \\
\text { Electricity } \\
(\mathrm{kW}-\mathrm{h})\end{array}$ & $\begin{array}{c}\text { Annual } \\
\text { Total } \\
\text { Electricity } \\
(\mathrm{kW}-\mathrm{h})\end{array}$ & $\begin{array}{l}\text { Annual } \\
\text { Energy } \\
\text { Cost }(\$)\end{array}$ & $\begin{array}{c}\text { Annual } \\
\text { Energy } \\
\text { Savings } \\
(\$)\end{array}$ & $\begin{array}{l}\text { Monthly } \\
\text { Energy } \\
\text { Savings } \\
(\$)\end{array}$ & $\begin{array}{c}\text { Saving } \\
\%\end{array}$ \\
\hline $\mathbf{A}$ & 819.72 & 5123.45 & 1147.65 & none & None & $\mathbf{n} / \mathbf{a}$ \\
\hline$\overline{\mathbf{B}}$ & 557.77 & 4843.23 & 1084.88 & 62.77 & 5.23 & 5.5 \\
\hline $\mathrm{C}$ & 720.20 & 2882.93 & 645.78 & 501.88 & 41.82 & 47.3 \\
\hline $\bar{D}$ & 713.25 & 2875.98 & 644.22 & 503.43 & 41.95 & 43.87 \\
\hline $\mathbf{E}$ & 554.28 & 2717.01 & 608.61 & 539.04 & 44.92 & 46.97 \\
\hline $\mathbf{F}$ & 751.21 & 2913.94 & 652.72 & 494.93 & 41.24 & 43.13 \\
\hline G & 651.69 & 2814.42 & 630.43 & 517.22 & 43.10 & 45.0 \\
\hline H & 803.78 & 2966.51 & 664.50 & 483.15 & 40.26 & 42.1 \\
\hline I & 760.29 & 2923.02 & 654.76 & 492.90 & 41.07 & 42.95 \\
\hline $\mathbf{J}$ & 807.78 & 2970.71 & 665.44 & 482.21 & 40.18 & 40.18 \\
\hline $\mathbf{K}$ & 709.32 & 2872.05 & 643.34 & 504.31 & 42.03 & 43.9 \\
\hline $\mathbf{L}$ & 819.72 & 2997.23 & 671.38 & 476.27 & 39.69 & 41.5 \\
\hline $\bar{M}$ & 727.33 & 2879.63 & 645.03 & 439.85 & 36.65 & 43.8 \\
\hline
\end{tabular}


Table 6: $\quad$ Results with air conditioning at all living areas.

\begin{tabular}{|c|c|c|c|c|c|c|}
\hline Case & $\begin{array}{c}\text { Annual } \\
\text { Cooling } \\
\text { Electricity } \\
(\mathrm{kW}-\mathrm{h})\end{array}$ & $\begin{array}{c}\text { Annual } \\
\text { Total } \\
\text { Electricity } \\
(\mathrm{kW}-\mathrm{h})\end{array}$ & $\begin{array}{l}\text { Annual } \\
\text { Energy } \\
\text { Cost }(\$)\end{array}$ & $\begin{array}{l}\text { Annual } \\
\text { Energy } \\
\text { Savings } \\
(\$)\end{array}$ & $\begin{array}{l}\text { Monthly } \\
\text { Energy } \\
\text { Savings } \\
\text { (\$) }\end{array}$ & $\begin{array}{c}\text { Saving } \\
\%\end{array}$ \\
\hline $\mathbf{A}$ & 2053.52 & 6803.25 & 1523.93 & None & None & $\mathbf{n} / \mathbf{a}$ \\
\hline$\overline{\mathbf{B}}$ & 1058.07 & 5745.18 & 1286.92 & 237.01 & 19.75 & 15.55 \\
\hline $\bar{C}$ & 1498.17 & 4107.34 & 920.04 & 603.88 & 50.32 & 39.63 \\
\hline D & 1486.17 & 4094.90 & 917.26 & 606.67 & 50.56 & 39.81 \\
\hline $\mathbf{E}$ & 1051.67 & 3660.40 & 819.93 & 704.00 & 58.67 & 46.20 \\
\hline $\mathbf{F}$ & 1734.56 & 4343.29 & 972.90 & 551.03 & 45.92 & 36.16 \\
\hline $\bar{G}$ & 1345.36 & 3954.09 & 885.72 & 638.21 & 53.18 & 41.88 \\
\hline H & 1958.23 & 4566.96 & 1023.00 & 500.93 & 41.74 & 32.87 \\
\hline I & 1405.21 & 4013.93 & 899.12 & 624.81 & 52.07 & 41.00 \\
\hline $\mathbf{J}$ & 1997.23 & 4605.96 & 1031.74 & 492.19 & 41.02 & 32.30 \\
\hline $\mathbf{K}$ & 1477.62 & 4086.35 & 915.34 & 608.59 & 50.72 & 39.94 \\
\hline $\mathbf{L}$ & 2053.52 & 4677.03 & 1047.65 & 476.27 & 39.69 & 31.25 \\
\hline $\mathbf{M}$ & 1495.35 & 4100.22 & 918.45 & 605.48 & 50.46 & 39.73 \\
\hline
\end{tabular}

The results were analyzed also in graphs to see more clearly the comparison between all the cases. Figure 5 shows the annual energy savings for all the cases in terms of dollars. In Figure 6 you can observe the energy savings percents. The Figure 7 shows the house sale price variation, this values was obtained in collaboration with Home Builders Association. The Figure 8 show net benefit from the new design. All of these graphs were prepared with the results obtained from the study. 


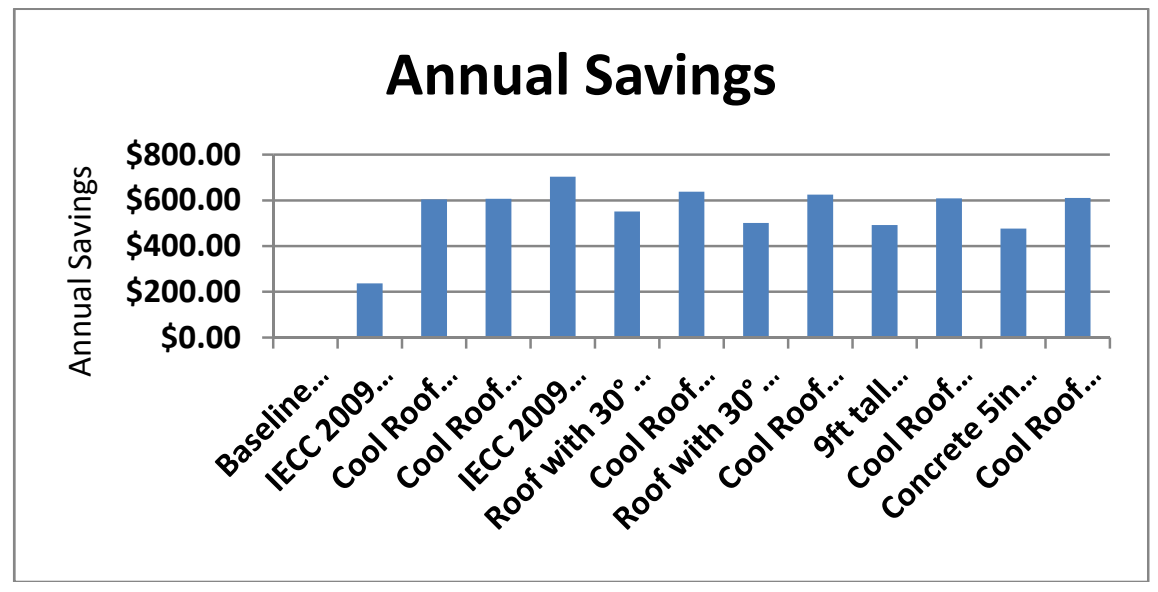

Figure 5: Annual energy savings for the design cases in terms of dollars.

\section{Energy Savings Percent}

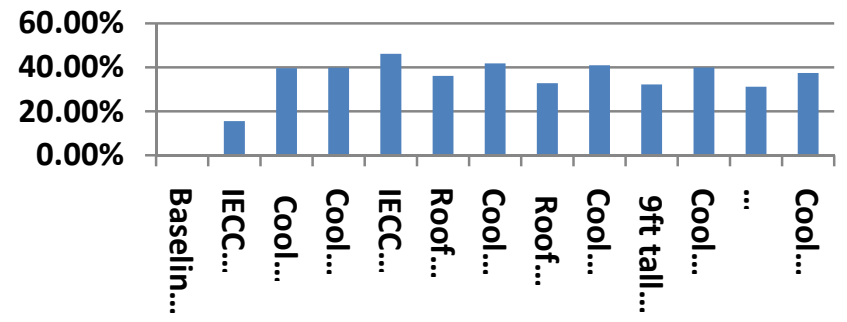

Figure 6: Energy savings percent obtained by the simulation process.

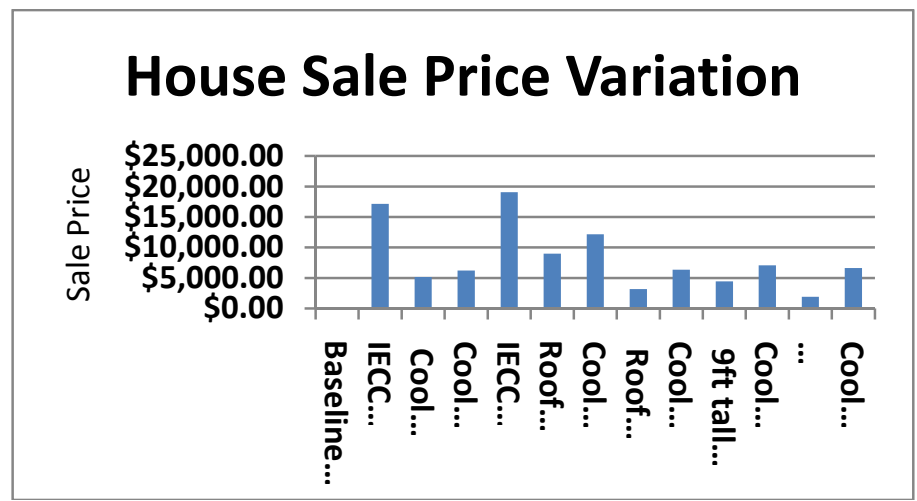

Figure 7: Sales price for all cases. This value represents the investment in the new materials added for the constructions. 


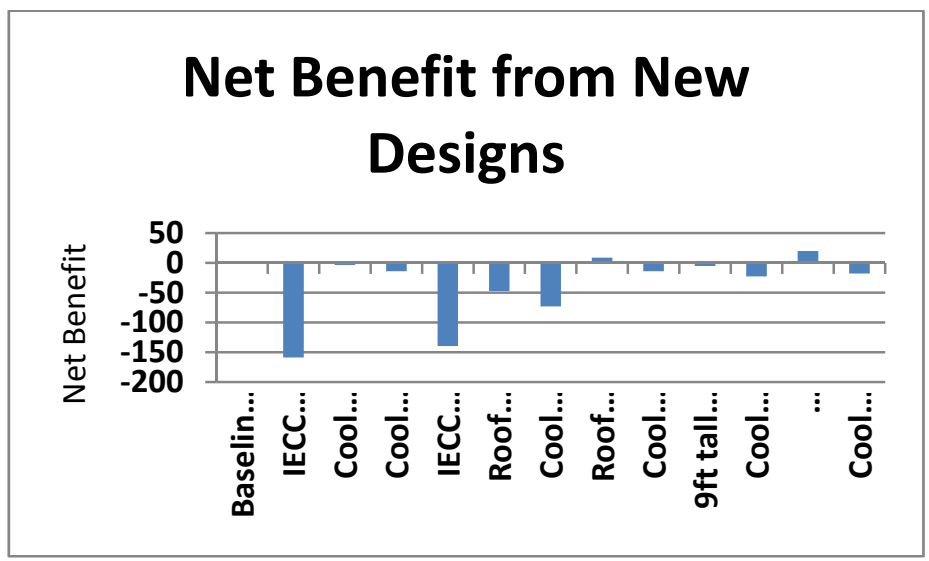

Figure 8: Net benefit obtained from the investment in the new designs.

\subsection{Analysis of the results}

The results obtained were based solely on energy consumption and each modification was compared to both the baseline and case B which was the case when the IECC 2009 standards were applied. For the baseline the yearly energy consumption was $5123.45 \mathrm{~kW}$-hr "see Table 5", if the IECC were to be implemented the energy consumption would be reduced by $15 \%$. This considerable reduction is difficult to achieve locally since most of the required materials are uncommon in the construction industry in Puerto Rico. Additionally, the increment in construction costs will affect sale prices and a possible decrease of sales will hurt the construction industry. One of the greatest contributor to the reduction in energy consumption is the use of solar water heater alone represents a total of $2,126 \mathrm{~kW}-\mathrm{hr}$ or $37 \%$ in energy savings. From economic stand point solar water heaters have small Return of Investments (less than 2 years) and can be used on an annual basis in Puerto Rico therefore all the other models were done using this technology. Case $G$ produces the highest energy saving at $45 \%$, this case consists of a gabled roof, the application of insulation at the roof and an attic. The thermal resistance for this configuration is R-15E. The case selected for its energy savings and economic impact was case $\mathrm{M}$ which produces $41 \%$ in savings.

For the simulations when the entire house is conditioned, as seen in Table 6 the baseline model showed an energy consumption of $6803.25 \mathrm{~kW}-\mathrm{hr}$. The most efficient case was case $\mathrm{G}$ again with energy savings totaling $41 \%$ and for the case $M$ savings of $37 \%$ were modeled

\section{Conclusions}

The results of the models used in this work showed possible energy savings that exceeded the savings estimated that the implementation of the IECC 2009 will have. The savings were attained without having to implement the suggested 
thermal resistance value of R-30. Up to a $41 \%$ in energy savings was attained with a thermal resistance of R-15. The results from this study were used to develop the new energy standard at the most recent building code for Puerto Rico. We have shown in detail that the use of a solar water heater alone represents a significant energy saving. The recommendations were based also on the economical impact any alteration will have on the sale price. The final recommendation was case $\mathrm{M}$ which has the standard 5 in walls and roof, but an insulating reflective material is applied at the roofs thereby increasing the thermal resistance.

The economical analysis part of this study was performed in order to validate the recommendations into the building code. Besides the solar water heater, all modifications to the structure or addition of new material will have a negative impact on the return of investment, but when combined with the solar water heater can be justified as an economical viable solution.

\section{References}

[1] http://www.parro.com.ar/index.php

[2] http://www.energycodes.gov/implement/state_code/index.stm

[3] http://apps1.eere.energy.gov/buildings/energyplus/

[4] Benitez, J.L. (200?); Impact Assessment of the Implementation of an energy Conservation Code for Low-Income Housing in P.R.

[5] Ruiz, G. (2011). Nuevo código de construcción impone regulaciones más estrictas. El nuevo Día, 40-41.

[6] Alva L. H., Gonzáles G.E. and Hertz J.B., Impact of construction materials in the energy consumption in homes in the Caribbean; International Solar Energy Conference, (2005) Orlando, Florida. 